\title{
PENGUASAAN LAHAN DAN DISTRIBUSI PENDAPATAN DI PEDESAAN
}

\author{
Oleb : Wabyuni Apri Astuti
}

\begin{abstract}
The main cause of the imbalance of the income distribution is the imbalance of land authority. One the important think that can not be ignored is the problem of land autbority non owner, from example trough the rented or share cropper. The land is not always done by the owner, the land owner who has narrow land sometimes rent out the land to the land owner has broad land, and be tend to become farmband on the other land owner. Tbus, it's possible that there is imbalance in the land authority on land and the distribution of the income.
\end{abstract}

\section{INTISARI}

Ketidakmerataan penguasaan lahan merupakan sumber utama ketidakmera. taan pendapatan. Satu bal yang tidak dapat diabaikan ialab masalab penguasaan laban bukan pemilikan dapat pula menentukan pendapatan petani. Penguasaan lahan bukan milik sendiri misal lewat sewa atau penyakapan. Laban yang dimiliki seseorang di pedesaan belum tentu digarap sendiri, pemilik laban yang terlalu sempit ada kalanya menyewakan labannya pada petani luas dan mereka cenderung menjual tenaganya sebagai burub tani. Dengan demikian dimungkinkan terjadi penguasaan laban yang timpang serta distribusi pendapatan menunjukkan bal yang sama.

\section{PENDAHULUAN}

Hingga saat ini masalah kemiskinan selalu merupakan permasalahan yang penting, terutama di negara-negara sedang berkembang. Hal ini disebabkan masih banyak masyarakat di negara-negara tersebut yang hidup dalam kondisi miskin. Oleh sebab itu perlu segera mendapat perhatian dan pemecahan agar masyakat yang hidup dalam kondisi miskin tersebut dapat memperbaiki tingkat penghidupannya.
Menurut Hadi Prayitno (1978 : 52) diperkirakan terdapat 68 persen penduduk pedesaan di Indonesia masih berada dalam keadaan miskin. Diperkirakan pada tahun 1970 di pedesaan Indonesia terdapat 53,74 juta jiwa atau 52,9 persen penduduk yang hidup di bawah garis kemiskinan, dengan 34,36 juta jiwa atau 33,74 persen yang hidup. nya tak cukup pangan. Sedangkan pada tahun 1980 jumlah penduduk yang hidup di bawah garis kemiskinan ada 45,43 juta jiwa atau 41,04 persen dan 
21,80 persennya merupakan penduduk miskin tak cukup pangan. Sementara itu di pedesaan Jawa jumlah penduduk yang hidup di bawah garis kemiskinan telah mengalami penurunan jumlahnya dari 39,97 juta jiwa atau sebesar 39,49 persen menjadi 21,01 juta jiwa atau 30,41 persen kclompok miskin tak cukup pangan.

Kemiskinan di pedesaan merupakan akibat rendahnya tingkat pendapatan per kapita yang diperoleh petani, karena sempitnya lahan yang dimiliki dan disebabkan pula karena keterbatasan kemampuan berusaha dan mendapatkan hasil dari sektor non pertanian.

Berbicara masalah pertanian dalam arti sempit, tidak terlepas dari tanah dimana usaha tani akan dilakukan. Tanah merupakan salah satu unsur yang mutlak bagi kchidupan manusia, tanah merupakan faktor yang diberikan oleh alam sehingga pembangunan tidak dapat terlepas dari hubungan antara tanah, dan manusia sebagai kesatuan.

Bagi masyarakat pedesaan, tanah bukan saja merupakan tempat tinggal, melainkan mempunyai peranan yang sangat penting yaitu sebagai sumber mata pencaharian. Namun di lain pihak tidak semua penduduk memiliki lahan pertanian, bagi yang memiliki lahan pertanian, pada umumnya sangat sem. pit. Beberapa penelitian di desa Jawa (Penny dan Singarimbun 1973, dan Mantra 1978) diperkirakan, sekitar 50 persen penduduk di daerah pedesaan di Jawa tidak memiliki lahan sawah, se. dang petani pemilik sebagian besar luas lahannya kurang dari 0,2 hektar.

Masaiah sempitnya pemilikan tanah pertanian di Jawa, telah lama dimaklumi oleh banyak peneliti. Penduduk di Jawa telah bertambah relatif cepat, sedangkan tanah pertanian hampir tidak bertambah. Kenyataan tersebut menimbulkan akibat antara lain makin kecilnya rata-rata pemilikan tanah, terjadinya fragmentasi lahan akan terjadi terus menerus.

Menurut sensus pertanian tahun 1973 dan 1980 menunjukkan dalam jangka waktu tersebut terdapat semakin berkurangnya jumlah rumah tangga yang mengerjakan lahan pertaniannya sendiri. Pada tahun 1973 terdapat 17.373.542 rumah tangga yang mengusahakan lahan pertaniannya sendiri, tetapi pada tahun 1980 telah menjadi 17.468.560 atau naik 2.7 persen per tahun. Namun jika dilihat dari jumlah pemilikan yang diusahakan sendiri nampak terjadi penurunan yaitu dari $10.746,522$ atau 74,8 persen pada tahun 1973 menjadi 73,6 persen pada tahun 1980 , tetapi jika dilihat secara absolut mengalami kenaikan menjadi 12.849.467 rumah tangga. Dilain pihak, jumlah rumah tangga yang mengusahakan tanah milik orang lain atau sebagai petani penggarap mengalami kenaikan dari 456.346 rumah tangga atau 3,2 persen pada tahun 1973 menjadi 2.601.791 rumah tangga atau 14,9 persen. Dilihat dari pemilikan luas tanah garapan petani, ternyata rumah tangga pertanian yang mengusahakan tanah pertanian kurang dari 0,5 hektar meningkat jumlahnya dari 6.560 .758 rumah tangga atau sebesar 45,6 persen pada tahun 1973 menjadi 11.027.654 rumah tangga atau sebesar 63,1 persen pada tahun 1980 dengan demikian terjadi kenaikan 9,7 persen setiap tahun. Rumah Tangga yang memiliki tanah pertanian lebih dari 0,5 hektar mengalami penurunan dari 7.812.784 rumah tangga atau sebesar 54,4 persen pada tahun 1973 menjadi 6.440 .374 rumah 
tangga atau sebesar 2,5 persen per tahun. Menurut Hadi Prayitno dan Lincolin Arsyad (1986) terdapat dua hal yang dapat disimpulkan dari kcadaan tersebut. Pertama, bertambahnya angkatan kerja sebagai akibat peledakan penduduk belum seluruhnya dapat diserap oleh sektor non pertanian, dan jumlah tenaga kerja yang masuk ke scktor pertanian sebagai petani dan buruh tani sebagai besar. Kedua, lahan pertanian yang diusahakan oleh rumah tangga pertanian semakin menyempit. Hal ini menyebabkan beban pada sektor pertanian menjadi berat karena semakin menyempitnya tanah pertanian dan makin banyaknya petani penggarap.

Menurut Dawan Raharjo (1984 : 22) masalah pokok yang dihadapi di daerah pedesaan adalah pengangguran atau semi pengangguran yang mencapai sekitar 20 persen atau lebih dari angkatan kerja. Soal kemiskinan absolut (rendahnya tingkat pendapatan dan kekayaan) berakar dari soal kesempatan kerja. Namun demikian dikatakan terdapat segolongan petani, yaitu sekitar 30 persen sampai 40 persen, yang telah meningkat pendapatannya.

Terdapatnya kepincangan pendapatan ini tentu saja merupakan ham. batan bagi proses pembangunan yang merata. Namun keadaan ini tidak dapat dihindari, karena hal ini merupakan akibat dari perbedaan pemilikan unsur-unsur produksi, terutama tanah. Kemampuan dalam penguasaan lahan ini mempengaruhi kemampuan akses petani terhadap sarana produksi, khususnya kredit yang disediakan oleh pemerintah. Hal ini tentu saja mengakibatkan perbedaan tingkat pendapatan diantara petani.

\section{BENTUK STATUS PENGUASAAN TANAH}

Ciri umum struktur dasar pertanian di Jawa adalah satuan usaha tani sangat sempit, serta terdapat berbagai bentuk status pemilikan tanah yang berdasarkan hukum formal dan hukum adat. Menurut $\mathrm{W} /$ /radi dan Makali (1984 : 47) konsep tentang hak atas tanah menurut hukum adat berbeda dengan konsep tentang hak atas tanah menurut hukum formal barat. Sebelum adanya undang-undang agraria kolonial 1970 , pengertian hak milik mutlak (eigendom, property) tidak dikenal. Setclah adanya undang-undang ini maka dikenal istilah-istilah antara lain hak pcrorangan turun temurun, hak komunal, hak milik mutlak dan sebagainya. Namun kenyataannya/dalam praktek nya bahkan sampai sekarang, periakuan-perlakuan dalam kelembagaan pertanahan secara adat dan penggunaan istilah-istilahnya masih dipakai.

Bentuk penguasaan tanah secara adat di Pulau Jawa secara garis besar (Kano, 1977; Wiradi dan Makali, 1984; Amaludin, 1987) adalah terdiri atas tanah bengkok, tanah titisara, tanah yasan dan tanah gogolan. Adapun yang dimaksud dengan tanah tersebut adalah sebagai berikut :

Pertama, tanah bengkok yaitu tanah pertanian yang pada umumnya berupa tanah sawah milik desa yang diperuntukkan bagi pamor desa terutama untuk kepala desa sebagai gajinya selama mereka menduduki jabatan kepada desa. Tetapi setelah tidak lagi menjabat sebagai pamong desa, maka tanah bengkok tersebut dikembalikan kepada desa dan dipcruntukkan bagi pejabat pengganti kepala desa.

Kedua, tanah titisara atau tanah 
bondo desa atau disebut pula tanah kas desa, yaitu tanah pertanian milik desa yang secara berkala biasanya disakapkan atau disewakan dengan cara dilelang. Kemudian hasilnya menjadi kekayaan desa, dan dipergunakan bagi keperluan desa untuk biaya pembangunan desa atau untuk mendukung anggaran rutin desa. Penggarapan tanah scmacam ini biasanya dilakukan melalui kontrak bagi hasil atau melalui penyewaan.

Ketiga, tanah yasan merupakan hak seseorang untuk menguasai sebidang tanah, dimana diperoleh dari usaha garapan. Di dalam konsep yasan, beberapa pengertian seperti hak menjual, menggadaikan dan menyewakan tidak termasuk di dalamnya. Ketiga pengertian tersebut baru dikenal setelah ada kontak dengan bangsa asing (barat). Menurut UUPA 1960 hak atas tanah ini memperoleh kedudukan hukum sebagai hak milik. Pada pemegang hak ini memiliki wewenang untuk melakukan penjualan atau pemberian terhadap tanah tersebut. Hak itu bersifat turun temurun dan berdasarkan hukum waris keluarga.

Keempat, tanah gogolan atau merupakan tanah pertanian milik masyarakat yang biasanya secara tetap atau dapat pula secara bergiliran digarap oleh sejumlah petani. Pemegang hak atas tanah ini diberi hak untuk mengerjakan tetapi tidak berhak untuk menjual atau memberikan kepada pihak lainnya. Petani yang mempunyai hak atas tanah garapan ini disebut petani gogol atau pekulen, kasikepan dan sebagainya. Pemegang hak atas tanah ini diberi kewajiban untuk menyumbangkan tenaganya kepada pemerintah desa untuk melaksanakan pekerjaan bagi kepentingan umum seperti kerja bakti, mela- kukan ronda dan scbagainya

Sctclah diundangkan UUPA 1960, maka tanah gogolan, tanah yasan dan sebagainya bcrubah statusnya menjadi hak milik perorangan dengan demikian pemilik tanah tidak harus lagi terikat oleh kewajiban untuk desanya atas tanah yang dikcrjakan tersebut. Sedangkan tanah titisoro dan tanah bengkok masih tetap ada.

\section{CARA MENGUKUR DISTRIBUSI PEN-} DAPATAN

Distribusi pendapatan dapat diukur dengan menggunakan beberapa cara antara lain dengan distribusi persentase pendapatan total berdasarkan persentil, model Bank Dunia dan dengan menggunakan indek GINI. Dengan ukuran tersebut akan diketahui tingkat ketimbangan distribusi pendapatan pada masyarakat tertentu.

Menurut ukuran distribusi pendapatan berdasarkan indeks persentil, yaitu dengan cara membagi populasi secara berturut-turut menjadi lima kelompok (quintiles) atau menjadi sepuluh kelompok (deciles) menurut tingkat kenaikan penghasilan dan kemudian menentukan proporsi yang mana dari jumlah penghasilan yang diterima oleh masing-masing kelompok penerima (Todaro, 1978: 192). Distribusi pendapatan dengan ukuran Quintiles membagi menjadi 5 kelompok masingmasing sebesar 20 persen. Quintiles atau lima kelompok pertama menggambarkan 20 persen dari populasi yang menerima paling rendah dalam skala penghasilan, sedang golongan teratas juga sebesar 20 persen. Kemudian dari proporsi itulah dapat dilihat bagaimanakah pendapatan total para penerimma itu tcrbagi diantara lima golongan 
tersebut.

Cara pengukuran distribusi penda. patan yang lain yaitu dengan menggunakan indeks GINI berupa angka yang terletak dari angka 0 yang menunjukkan distribusi pendapatan merata secara sempurna, sampai angka satu yang menunjukkan distribusi pendapatan yang amat timpang. Atau dapat dikatakan semakin mendckati nol, berarti makin baik distribusinya, sebaliknya semakin mendekati angka satu berarti distribusi makin buruk atau makin timpang. Kriteria ketimpangan pendapatan berdasarkan indeks GINI adalah se. bagai berikut (Tjiptoheriyanto, 1982) pertama, tingkat ketimpangan distribusi pendapatan tinggi jika indeks GINI lebih dari atau sama dengan 0,50 ; kedua tingkat ketimpangan distribusi pendapatan sedang apabila angka indeks GINI berkisar antara 0,40 sampai 0,49 dan tingkat ketimpangan distribusi rendah jika angka indeks GINI 0,40 . Angka Gini Coefficient sama dengan 0 (merata mutlak) dan angka GINI Coefficient sama dengan 1 (tidak merata mutiak) adalah tidak mungkin terjadi dalam kenyataan. Menurut Todaro, untuk negara-negara sedang berkembang distribusi pendapatan sangat timpang dan angka GINI terletak antara 0,50 sampai 0,70 dan relatif sama ketimpangan distribusi pendapatan bila angka Gini antara 0,20 sampai 0,35 . Pola distribusi pendapatan masyarakat yang didasarkan pada hasil perhitungan Gini Ratio barulah menggambarkan tingkat pemerataan pendapatan sccara global. Sejauhmana atau berapa bagian yang diterima oleh kelompok berpendapatan terendah belum nampak jelas. Sehubungan dengan ini, ukuran yang dikembangkan oleh Pusat Penelitian Bank Dunia memberi gambaran lebih jelas mengenai masalah ketidakadilan melalui indikator yang discbut relative incquality.

Relative incquality diartikan sebagai ketimpangan dalam distribusi pendapatan yang diterima oleh berbagai golongan masyarakat. Adapun kriteria relative inequality dari Bank Dunia adalah: pertama, apabila kelompok terbawah (40 persen dari populasi) menerima bagian pendapatan lebih dari 17 persen, maka tingkat ketimpangan distribusi pendapatan digolongkan rendah (low inequality); kedua jika kelompok 40 persen terbawah menerima bagian pendapatan antara 12 hingga 17 persen dari toral pendapatan masyarakat berarti termasuk tingkat ketimpangan sedang (moderate inquality) dan ketiga jika kelompok 40 persen terbawah dari populasi meneri. ma bagian pendapatan kurang dari 12 persen dari total pendapatan masyarakat maka digolongkan ketimpangan tinggi (high inequality).

Karena mata pencaharian petani di pedesaan sangat tergantung pada lahan pertanian, maka keterkaitan antara penguasaan lahan dan distribusi pendapatan perlu mendapat perhatian. Untuk mengukur distribusi penguasaan lahan juga dapat dicari dengan cara tersebut diatas.

\section{PENGUASAAN LAHAN DAN DIS- TRIBUSI PENDAPATAN}

Distribusi penguasaan lahan cende. rung tidak merata di pedesaan, yang menyebabkan makin tidak meratanya pendapatan di pedesaan atau kepincangan pendapatan masyarakat pedesaan. Angka koefisien Gini dari distribusi penguasaan lahan di Indonesia mencapai 0,532 (Anne Booth dan Sun- 
drum, 1973: 95). Angka Gini untuk Indonesia menurut Booth \& Sundrum, tergolong cukup tinggi. Adanya polarisasi penguasaan lahan, mendukung makin tidak meratanya pendapatan masyarakat desa. Dari penelitian Herman Suwandi (1976) di delapan desa di Jawa Barat, serta hasil pengamatan Siahaan di Jawa Tengah (1977) dalam Soentoro, 1981: 3 dijelaskan bahwa petani luas lebih cepat mengadopsi teknologi baru daripada petani sempit. Selanjutnya adanya pemanfaatan teknologi baru oleg petani luas menyebabkan makin melebarnya disparitas pendapatan pada masyarakat desa.

Pengamatan White dan Wiradi (1989: 49) menyatakan bahwa:

Ketidakmerataan dalam penguasaan tanah merupakan sumber utama dari ketidakmerataan dalam penycbaran pendapatan. Gejala meluasnya konscntrasi pemilikan lahan, justru berlang. sung sejak pemerintah berusaha melaksanakan landreform pada waktu UUPA tahun 1960 dicoba untuk dilaksanakan (William Collier, 1979: 30). Pembagian kembali lahan terjadi, tapi tahun 1965 telah berbalik seperti semula. Justru UUPA tahun 1960 membawa perubahan besar, yaitu mengubah konsep bentuk penguasaan lahan desa oleh masyarakat setempat menjadi hak penguasaan perseorangan terhadap lahan setempat. Menurut William Collier, ini semua memudahkan petani di Jawa menjual lahan kepada penduduk setempat serta memungkinkan orang dari luar desa menguasai lahan. Hal ini merupakan kesempatan yang terbuka menuju ke proses konsentrasi pemilikan lahan pedesaan. Proses pemilikan lahan yang dikuasai oleh beberapa atau kelompok kecil orang, makin bertambah. Demikian pula laju pemilikan la- han absentee bertambah dengan cepat. Proses pengelompokan dan penjualan tanah kepada orang lain di luar desa akan merusak welfare institution masyarakat desa, misalnya hilangnya sistem bawon yang memudahkan pekeriaan tolong menolong antar penduduk pedasaan.

Seperti tclah diutarakan di atas bahwa lahan yang dimiliki seseorang di pe. desaan, belum tentu digarap sendiri. Ada kalanya petani yang memiliki lahan terlalu sempit malah cenderung untuk menyewakan pada orang lain, yaitu petani yang lebih luas usahanya, sedangkan mereka sendiri lebih suka menjual tenaganya untuk mendapatkan upah sebagai buruh tani. Pemilik lahan luas dapat mengambil dua sikap, pertama memperkerjakan buruh pada usaha taninya atau sikap yang lain yaitu menyewakan tanahnya pada petani penggarap. Disinilah timbul sistem penggarapan baru lahan pertanian yaitu berbentuk sewa menyewa atau penyakap. an (dengan sistem bagi hasil).

Menurut Dawam Raharjo (1981: 49) bahwa pemilikan lahan lebih- lebih yang terlalu sempit atau terlalu luas, tidak selalu berpengaruh menentukan pembagian pendapatan tetapi yang perlu diperhatikan adalah soal penguasaan lewat sewa atau penyakapan.

Berdasarkan tentang permasalahan pemilikan lahan beserta pendapatan di daerah pedesaanm, ternyata berbagai hasil penelitian menujukkan berbabagi variasi, walau variasi tersebut tidak begitu menyolok. Singarimbun dan Penny (1976) menyatakan bahwa pemilikan lahan di desa Sriharjo Bantul Yogyakarta menunjukkan adanya distribusi yang buruk dimana 40 persen lapisan terendah yang miskin hanya menguasai 10,2 persen dari luas tanah pertanian desa. 
Di lain pihak terdapat 20 persen lapisan tertinggi yang merupakan golongan kaya di desa tersebut ternyata menguasai lahan mencapai 62,8 persen dari luas lahan pertanian yang ada. Penclitian tersebut dilakukan di dacrah dataran rendah dan merupakan lahan sawah irigasi, ternyata terdapat distribusi pemilikan tanah yang dikuasai oleh segolongan kecil lapisan masyarakat.

Hasil penelitian Wiradi dan Makali (1983) mengatakan bahwa ada hubungan yang cukup kuat antara struktur pemilikan lahan dengan struktur pendapatan di daerah pedesaan. Struktur pemilikan tanah menunjukkan adanya lapisan tanah sempit dan mereka yang tidak memiliki tanah, serta proporsi keluarga miskin yang lebih besar daripada pemilik tanah yang luas. Iİal ini berarti bahwa pemilikan tanah tetap merupakan faktor yang turut menentukan tingkat hidup pedesaan. Hasil penelitian tersebut juga menyatakan bahwa di daerah pedesaan Jawa sedang terjadi proses pemusatan penguasaan tanah, baik melalui sewa menyewa, gadai, maupun melalui pembelian.

Dalam hubungannya dengan penguasaan lahan dan disparitas pendapatan, digunakan variabel adopsi inovasi sebagai test factor (Hotman Siahaan, 1977: 48). Sebagai test factor, variabel adopsi inovasi adalah merupakan intervening variabel dalam hubungan antara independent variabel yaitu (pemilikan lahan) dengan dependent variabel (disparitas pendapatan). Ketidaksamaan kemampuan para petani modern, akibat perbedaan luas pemilikan tanah akan menimbulkan perbedaan (disparitas) pendapatan dari berbagai golongan petani. Hasil pertanian menunjukkan bahwa 62,5 persen petani kaya yang berpendapatan tinggi ada- lah mereka yang tingkat adopsinya tinggi, 12,5 persen berpendapatan menengah dan 25 persen berpendapatan rendah. Bilamana dibandingkan dengan petani kaya yang tingkat adopsinya rendah maka golongan petani ini yang berpendapatan tinggi hanya 12,5 persen, berpendapatan menengah 75 persen dan berpendapatan rendah 12,5 persen. Sedangkan golongan petani miskin yang tingkat adopsinya tinggi, mereka yang berpendapatan tinggi 40 persen dibandingkan dengan 40 persen pendapatan menengah dan hanya 20 persen berpendapatan rendah. Bagi petani miskin yang tingkat adopsinya rendah terlihằt bahwa mereka yang berpendapatan tinggi meliputi 2,9 persen, menengah 8,1 persen dan yang berpendapatan rendah meliputi 89 persen. Dengan demikian perbedaan luas pemilikan lahan dan penguasaan lahan yang berkorelasi positif dengan disparitas pendapatan adalah akibat perbedaan kemampuan untuk memanfaatkan unsur-unsur teknologi pertanian modern pada masyarakat pedesaan.

Dalam studi kasus tentang respon petani terhadap teknologi baru di Jawa Barat, Herman Suwardi (1976) menyatakan bahwa petani luaslah yang lebih respon terhadap penggunaan teknoiogi baru pada usaha tani padi. Hal yang sama telah dilaporkan oleh Siahaan (1977) pada penelitian di Jawa Tengah yang menyatakan bahwa disparitas penguasaan tanah menyebabkan adanya disparitas penggunaan teknologi baru yang selanjutnya berhubungan erat dengan disparitas pendapatan.

Distribusi pendapatan dapat mencerminkan kondisi kemerataan atau ketimpangan pendapatan yang terdapat di suatu wilayah. Berdasarkan tingkat pendapatannya suatu masyarakat se- 
cara relatif dapat dikelompokkan menjadi tiga strata yaitu: strata bawah atau golongan miskin (lemah) meliputi 40 persen jumlah penduduk, strata tengah atau golongan cukupan meliputi 40 persen jumlah penduduk, dan strata atas atau golongan kaya meliputi 20 persen jumlah penduduk (Suhardjo, 1988: 28)

Menurut Irlan Sujono (1978), pendekatan analistis dalam menilai distribusi pendapatan dapat dibedakan menjadi dua, yakni: pertama, distribusi pendapatan relatif fungsional dan kedua distribusi pendapatan relatif terhadap total. Menurut Soebardi (dalam Suhardjo 1988), bahwa distribusi pendapatan fungsional kurang cocok jika digunakan untuk menaksir distribusi pendapatan suatu masyarakat, dimana kegiatan ekonomi para anggota masyarakat tercermin dalam fungsi produksi yang bermacam-macam. Diferensiasi pendapatan diantara golongan dalam masyarakat dapat menunjukkan merata tidaknya distribusi pendapatan dalam masyarakat.

Menurut Sayogya (1982) semakin luas usaha tani semakin besar persentase penghasilan rumah tangga pertanian, tetapi bagi rumah tangga petani yang memiliki lahan kurang dari 0,25 hektar atau tak mempunyai lahan, maka usaha di bidang jasa, dagang dan kerajinan mempunyai arti yang amat penting. Dengan demikian jika rumah tangga yang mempunyai tingkat pendapatan semakin rendah, maka semakin banyak dan beraneka sumber mata pencahariannya.

Menurut Penny dan Singarimbun (1983) bahwa untuk hidup layak penduduk pedesaan atau kecukupan dengan jumlah anggota keluarga rumah tangga sebanyak 5 jiwa, maka jika mengolah 0,7 hektar sawah dan 0,3 hektar tanah kering dimana mercka dapat menanam kelapa, sayuran, buahbuahan, pohon-pohonan lain serta keperluan rumah tangga lainnya. Sedangkan menurut Sayogya (1982: 2) bahwa petani miskin adalah petani yang pekerjaan pokoknya menggarap lahan usaha tani sawah dengan luas kurang dari 0,50 hektar, schingga dikategorikan berada di bawah garis kemiskinan (Hadi Prayitno dan Lincolin Arsyad, 1987: 88),

Proses pengelompokan pemilikan lahan yang dikuasai hanya beberapa atau kelompok kecil orang, makin bertambah. Demikian pula lahan absentee juga bertambah dengan cepat. Mengenai situasi pertanahan di Indonesia adalah sempitnya lahan pertanian dalam satuan yang terpecah-pecah atau fragmented. Jika dilihat perkembangan tahun 1973-1983 persentase pemilikan lahan 0,10-0,25 hektar menurun dari 26 persen menjadi 17 persen, sedangkan pada kelompok 0,25- 0,50 hektar meningkat dari 30 persen menjadi 38 persen. Ada dugaan bahwa penurunan pemilikan yang kurang dari 0,25 hektar disebabkan lahan itu terkonsentrasi ke dalam kelompok 0,25-0,50 hektar. Dengan perkataan lain, jumlah rumah tangga yang tidak memiliki tanah semakin meningkat (Manning, 1986: 20). Menurut data Biro Pusat Statistik terlihat bahwa terdapat kepincangan dalam hal luas tanah garapan dengan persentase tertinggi terdapat pada golongan luas lahan dibawah 0,5 hektar sebesar 45,6 persen, 0,5 sampai 1,0 hektar sebesar 27,7 persen dan 1,0 sampai 5,0 hektar sebesar 27,5 persen, 5,0 sampai 10,0 hektar sebesar 1,6 persen dan di atas 10 hektar sebanyak 0,6 persen pemilik (BPS, 1977: 37). 
Situasi tahun $1973-1980$ berdasar kan sensus penduduk bahwa persentase jumlah usaha tani milik sendiri tclah merosot dari 76,5 persen pada tahun 1973 menjadi 73,5 persen pada tahun 1980 , sedangkan yang tak memiliki sendiri dari 12,1 persen tahun 1973 menjadi 14,9 persen pada tahun 1980 . Jumlah usaha tani milik sendiri dan orang lain adalah 11,5 persen pada tahun 1973 menjadi 11,6 persen pada tahun 1980 (BPS, 1980: dalam Dawan Raharjo, 1984: 43). Persoalan ini menimbulkan persoalan kesempatan kerja, karena perluasan kesempatan kerja dalam sektor pertanian sudah sangat terbatas.

Terbatasnya kesempatan kerja di sektor pertanian, menyebabkan mereka mencari tambahan pekerjaan di luar sektor pertanian. Mobilitas sirkuler tidak dapat dilepaskan dari siklus pertanian. Menurut Hugo (1975) migrasi sirkuler sering disebut migrasi bermusim, karena erat hubungannya dengan volume mobilitas sirkuler yang sangat bervariasi sepanjang tahun. Mantra (1978) juga menyatakan bahwa volume migrasi erat kaitannya dengan musin. Pada bulan April sampai September intensitas migrasi sirkuler umumnya sangat tinggi karena pada masa itu sedang tidak ada pekerjaan di sawah di pedesaan.

Peningkatan cepat dalam pekerjaan di luar sektor pertanian dan pekerjaan non pertanian sejak 1970 dapat diinterpretasikan sebagai indikator ketidakseimbangan antara kapasitas penyerapan tenaga kerja di bidang perta. nian dengan angkatan kerja yang bertambah terus (Irwan Abdullah, 1991: 3). Selanjutnya dikatakan bahwa perubahan tersebut menumbuhkan bebe. rapa konsékuensi: (i) perbedaan antara petani kaya dan miskin menjadi se- makin tampak, yakni distribusi pendapatan menjadi tidak adil; (ii) pendapatan di pedesaan khususnya bagi buruh upahan menurun; dan (iii) migrasi desa-kota dan urbanisasi menjadi me. ningkat. Hasil penelitian Wiradi dan Makali (1983) di 12 desa di Jawa dan 3 desa di Sulawesi Selatan menunjukkan bahwa ternyata sektor non pertanian memberikan sumbangan lebih dari 50 persen total pendapatan.

Satu hal yang tidak dapat diabaikan ialah masalah penguasaan lahan bukan pemilikan dapat pula menentukan pendapatan petani. Menurut White dan Wiradi (1979: 49) ketidakmerataan da. lam penguasaan tanah merupakan sumber utama dari ketidakmerataan dalam penyebaran pendapatan. Pendapat yang senada juga dikemukakan Dawan Raharjo (1984: 49) faktor yang menjadi bahan pertimbangan adalah bahwa pemilikan lahan lebih-lebih yang terlalu sempit atau terlalu luas tidak selalu berpengaruh dalam menentukan pembagian pendapatan. Faktor yang perlu diperhatikan justru adalah penguasaan lahan lewat sewa atau penyakapan. Lahan yang dimiliki belum seseorang di pedesaan belum tentu digarap sendiri, pemilik lahan yang terlalu sempit ada kalanya menyewakan lahannya pada petani pemilik lahan luas dan mereka cenderung menjual tenaganya sebagai buruh tani.

Penguasaan lahan pada umumnya menunjukkan pada kondisi pada kemampuan, kesempatan dan atau hak memperoleh dan memiliki lahan perta. nian dalam rangka untuk memperoleh hasil produksi pertanian atau produksi lain dari lahan tersebut. Penguasaan la. han dapat berupa penguasaan pemilik. an dan penguasaan non pemilikan lewat sewa atau melalui penyakapan. 
Penguasaan lahan pemilikan, lahan pertanian yang dikuasai sckaligus merupakan hak miliknya schingga dapat dipindah tangankan atau dijual pada orang lain, diberikan pada orang lain sehingga lahan pemilikan dapat berpindah penguasaannya, tetapi lahan non pemilikan sifatnya hanya sementara sesuai perjanjian kedua belah pihak dan mudah terjadi penggantian hak penguasaan lahan non pemilikan pada orang lain.

Undang-undang Pokok Agraria tahun 1960 membedakan hak kekuasaan tanah menjadi dua "kelompok yaitu: hak atas tanah dan hak jaminan atas tanah. Dalam hak atas tanah yang menentukan sistem penguasaan tanah dibagi menjadi dua yaitu (i) hak primcr, ialah scmua hak yang diperoleh langsung dari negara dan (ii) hak sekunder yaitu semua hak yang berasal dari pemegang hak atas tanah lain berdasarkan pada perjanjian bersama. Persamaan dari kedua hak tersebut adalah pemegangnya berhak menggunakan ta. nah yang dikuasainya untuk dirinya sendiri atau mendapatkan keuntungan dari orang lain melalui perjanjian dimana satu pihak memberikan hak-hak sekundernya pada orang lain (Budi Harsono, 1983: 7).

Menurut Ari Sukanti (1985: 34) hak atas tanah yang diperolch dari negara terdiri atas hak milik, hak guna usaha, hak guna bangunan, hak pakai dan hak pengelolaan; sedangkan hak sekunder terdiri atas hak usaha bagi hasil, hak gadai dan hak menumpang. Dalam pasal 53 UUPA menentukan bahwa hak usaha bagi hasil, hak sewa dan hak gadai tanah pertanian akan dihapuskan. Menurut Budi Harsono (1973: 5) azasazas yang tercantum dalam UUPA yang menyatakan bahwa tanah pertanian ha- rus diolah olch pemiliknya sendiri, tetapi menurut realitasnya yang ada bahwa azas ini belum terlaksana sepenuhnya.

UUPA disusun dalam upaya untuk meratakan pemilikan lahan di Indonesia dan dimaksudkan untuk memperbaiki struktur hal milik atas tanah di pedesaan. UUPA menginginkan agar di satu pihak para petani memperoleh lahan yang cukup diperlukan untuk bisa meningkatkan kesejahteraannya di atas garis kemiskinan, dan tanah yang digarapnya bukan hanya cukup luasnya melainkan juga miliknya sendiri. Tetapi di lain pihak undang-undang ini juga ingin mencegah terjadinya konsentrasi pemilikan lahan pada sekelompok kecil elite desa (Dawam Raharjo, 1984: 51). Lébih lanjut dikatakan bahwa konsentrasi lahan ini tidak dikehendaki karena dianggap sebagai sumber kepincangan sosial-ekonomi dalam masyarakat pedesaan, tetapi juga alasan efisien, yaitu (i) karena lahan yang digarap dengan sistem sewa atau bagi hasil kurang efisien dibanding kalau digarap sendiri oleh pemiliknya dan (ii) sistem itu menyebabkan pendapatan petani penyewa atau penyakap bahkan juga si pemilik lahan lebih rendah. Atas dasar ituiah maka lahan pertanian yang pemilikannya mengelompok ke atas perlu didistribusikan kembali. Dengan demikian, maka landreform ingin dijalankan dengan dua alasan yaitu : (i) untuk meratakan pendapatan masyarakat, serta (ii) untuk meningkatkan pendapatan petani.

Seperti juga pendapat/gagasan Myrdal dan Amarta dalam Dawam Raharjo (1984) bahwa Myrdal menghendaki agar petani menggarap tanahnya sendiri agar lebih efisien, sedangkan Sen mengatakan bahwa lahan yang sempit 
ternyata lebih efisien dari usaha tani luas. Oleh sebab itu kombinasi dari pemikiran tersebut membentuk gagasan untuk mengembangkan sistem bertani atau usaha tani yang didukung oleh satuan-satuan usaha tani kecil tapi efisien karena digarap pemiliknya sendiri. White dan Wiradi (1979) bahwa distribusi luas usaha tani menurut kelompok usaha tani belum tentu atau tidak selalu mencerminkan pola distribusi pemilikan lahan. Selanjutnya dikatakan bahwa ketidakmerataan penguasaan lahan merupakan sumber utama ketidak. merataan pendapatan.

Pendapat Sinaga dan Kasyanto (1980 : 41) menyatakan bahwa, golongan petani yang lebih efisien adalah petani penggarap, kemudian petani penyewa dan petani penyakap. Atau dapat dikatakan bahwa, sistem sewa (kontrak) perlu dikembangkan lebih lanjut untuk menggantikan sistem bagi hasil. Tetapi sebagian orang lebih cenderung untuk memilih jalan reformis, yaitu dengan memperbaiki sistem dan struktur yang ada. Tujuannya untuk meningkatkan produktivitas pada usaha tani kecil atau menengah, dengan memanfaatkan program modernisasi pertanian. Agar lebih menguntungkan petani penggarap, maka dilakukan melalui perbaikan sistem bagi hasil, atau mengubah sistem bagi hasil ke arah kontrak sewa yang saling menguntungkan.

Suatu kenyataan bahwa di pedesaan Jawa penguasaan lahan sangat timpang. Menurut hasil penclitian dari S $\Lambda \mathrm{E}$ dalam Wiradi (1985:46) dari scpuluh desa yang ditcliti menunjukkan tubuh diantaranya menunjukkan angka kocfisien Gini di atas 0,70, scdangkan tiga desa lainnya diatas 0,55. Demikian pula distribusi pendapatan menunjuk- kan hal yang sama, besarnya indeks Gini tersebut untuk penguasaan tanah dan pendapatan mempunyai korelasi yang sangat signifikan. Berbagai studi kasus tentang kehidupan sosial ekonomi pctani di pedesaan Jawa seperti yang dilakukan Hayami, Kano dan SAE mengungkapkan bahwa struktur agraris di pedesaan Jawa ditandai oleh ketimpangan penguasaan lahan yang cukup tajam (Hayami dan Kikuchi 1981: 177 - 179; Hotman P. Siahaan, 1984 : 52 - 54; Kano dalam Tjondronegoro dan Gunawan Wiradi, 1984 : 239 . 243).

\section{KESIMPULAN}

Berdasarkan uraian di atas dapat disimpulkan hal-hal sebagai berikut :

Pertama, distribusi penguasaan lahan di pedesaan cenderung terjadi ke. tidakmerataan. Hal ini menyebabkan makin tidak meratanya pendapatan di pedesaan atau dengan kata lain terjadi kepincangan pendapatan masyarakat pedesaan.

Kedua, adanya polarisasi penguasaan lahan serta pemanfaatan teknologi baru olch petani luas mendukung makin tidak meratanya pendapatan pada masyarakat desa.

Ketiga, penguasaan lahan bukan milik mempunyai peranan dalam hal pendapatan, karena pemilik lahan sempit belum tentu menggarap lahannya hal ini disebabkan terbatasnya modal dan mereka biasanya memilih menjadi buruh tani.

Kecmpat, untuk meningkatkan perckonomian masyarakat desa, peranan sektor non pertanian sangat penting. Hal ini dapat dimengerti karena kesempatan kerja di bidang pertanian sangat tcrbatas. 


\section{DAFTAR PUSTAKA}

Amaludin, Moh, 1987. Kemiskinan dan Polarisasi Sosial (Studi Kasus di Desa Bulugede, Kabupaten Kendal, Jawa Tengah, Tesis S2, Jakarta.

Ari Sukanti Hutagalung, 1985. Program Redistribusi Tanah di Indonesia, Suatu Sarana ke Arah Pemecahan Masalah Penguasaan Lahan dan Pemilikan Tanah, CV Rajawali, Jakarta.

Hadi Prayitno dan Lincolin Arsyad, 1987. Petani Desa dan Kemiskinan, Badan Penerbit Fakultas Ekonomi Universitas Gadjah Mada, Yogyakarta.

Hayami, Yujiro dan Masao Kikuchi, 1981. Asian Village Economy at the Crossroads, University of Tokyo Press.

Kano, Hiroyoshi, 1977. Penguasaan Tanah dan Differensiasi Masyarakat Desa, dalam Propek Pembangunan Ekonomi Pedesaan Indonesia, Yayasan Obor, Jakarta.

Kasryno, Faisal, 1983. Perkembangan Penyerapan Tenaga kerja di Indonesia Berdasarkan Data Sensus Penduduk Tahun 1971 - 1980. Kerjasama BPS dan Pusat Penelitian Studi Kependudukan Universitas Gadjah Mada University Press, Yogyakarta.

....., 1984. Prospek Pembangunan Ekonomi Pedếsaan Indonesia, Yayasan Obor Indonesia, Jakarta.

Penny, D.H., dan Meneth Ginting, 1984. Pekarangan, Petani dan Kemiskinan, Gadjah Mada University Press, Yogyakarta.

Raharjo, Dawam, 1984. Transformasi Pertanian, Industrialisasi dan Kesempatan Kerja, Penerbit Universitas Indonesia, Jakarta.

Sajogyo, 1978. Lapisan Masyarakat Yang Paling Lemah di Pedesaan, Prisma, No. 3, April, Jakarta.

Singarimbun, Masri dan Penny, D.H., 1976. Penduduk dan Kemiskinan Kasus Sriharjo di Pedesaan Jawa, Bhatara Karya Aksara, Jakarta.

Suhardjo, A.J., 1988 Peranan Kelembagaan Dalam Hubungan Dengan Komerslalisasi Usaha Tani dan Distribusi Pendapatan: Studi Kasus di Daerah Pegunungan Kabupaten Banjarnegara, Jawa Tengah, Disertasi Fakultas Geografi UGM, Yogyakarta. 